\title{
The geopolitics of Central Asian energy
}

\author{
Jaewoo Choo
}

This chapter assesses the rising geostrategic and geoeconomic importance of Central Asian oil and natural gas for China and the United States - the most transparent source of Sino-American conflict in this region. The initial rationale for Chinese engagement in Central Asia, despite the emergence of China as a net oil-importing nation in 1993, was not driven by the search for an alternative and secure source of oil and natural gas. ${ }^{1}$ Rather, Chinese policy reflected a set of domestic and foreign policy concerns, particularly the desire to address unresolved border disputes with its many neighbours, to dampen ethnic unrest in the Xinjiang autonomous province, to foster regional economic cooperation, to open new markets for Chinese arms, and to reduce the incidence of drug trafficking and illegal migration. ${ }^{2}$ American interest in the region was closely linked to the Clinton strategy of engagement and enlargement, particularly the desire to facilitate the transition to democracy and the market economy in the states spawned by the dissolution of the Soviet Union. But as the gap between the demand and domestic supply of oil widened in both countries, the oil-producing states of Central Asia took on a new significance. Both the Chinese and American governments have sought privileged access to this region for their national oil firms. ${ }^{3}$

Sino-American competition in this region began in earnest in $1994 .{ }^{4}$ China seemed to be better positioned initially, owing to successive annual summit meetings with the regional oil-producing states - Russia, Kazakhstan, Kyrgyzstan and Tajikistan. These meetings resulted in the creation of the 'Shanghai Five' in 1996, a grouping that was subsequently enlarged with the addition of Uzbekistan in 1999 and formalised in 2001 with the creation of the SCO. ${ }^{5}$ The Shanghai process generated cooperation agreements in various issue areas, ranging from border disputes to economic cooperation to anti-terrorism measures. In this way, China established a firm diplomatic presence in the region.

The September 11 terrorist attacks on New York and Washington, DC, 
however, have had a lasting effect on the trajectory of Sino-American competition in Central Asia. The subsequent American retaliation on the Taliban and al-Qaeda in Afghanistan generated the not unwelcomed externality of expanding the American sphere of influence in the region. American military operations required the acquisition of military basing rights, and the United States was able to deploy and base its troops along Afghanistan's perimeter in Uzbekistan, Turkmenistan and Kyrgyzstan in exchange for considerable sums of humanitarian aid and economic assistance. The basing of American forces in these Central Asian states initially raised concerns in Russia, China, Iran and even Turkey. Despite the American claim that the US military presence in the region was temporary and contingent on the war on terrorism, the world in general, and Russia and China in particular, were very much concerned that this temporary deployment of American troops would become permanent and formalised in a set of bilateral treaties. At this juncture, it appears certain that the duration and nature of the US military presence in Central Asia will extend into the medium term, an assessment in keeping with the immediate challenge of counter-insurgency warfare in Afghanistan and the longer-term challenge of waging the war on terrorism.

The longer the duration of the American military presence in Central Asia, the more anxious will China be. Just as the United States was discomfited by the rising influence of China and Russia in the region prior to September 2001, China and Russia are now discomfited by the rising American role and influence there, despite their (self-interested) support of the US campaign against terrorism. ${ }^{6}$ China, in particular, faces an acute geostrategic dilemma. Whether it be NATO's PfP programme, the OSCE, or the signing of bilateral military agreements with states in the region, China views these American initiatives, even if they have been directed at the disinterested goal of regional stability, as a putative threat to Chinese regional interests (just as many in Washington have viewed the SCO as a threat to American interests). These divergent geostrategic assessments raise a few interesting questions: are American and Chinese interests in fact opposed in the region? Is the nascent security regime embodied in the SCO inherently incompatible with the Atlantic security system? Will the development and exploitation of Central Asian energy be hindered or precluded by the clash of Chinese and American geostrategic interests in the Pacific? Answers to these questions will inevitably be conditioned by the negative perceptions that Chinese and American foreign policy elites have of one another and the power vacuum in Central Asia that has invited the major powers to stake an exclusive leadership claim there. While Chinese diplomatic options are increasingly constrained by the rapprochement between Russia and NATO and the dependence of Pakistan and India on American patronage to broker the Kashmir dispute, the 'Great Game' for influence and control of this region could none the less be replayed by the United States and China. 
Increasingly, such an outcome could be fuelled as much by a competition for future rights to Central Asian oil reserves as by concerns over geostrategic advantage.

\section{The rising geostrategic and geoeconomic importance of Central Asia}

Prior to the September 11 terrorist attacks, Central Asia was already an important region in the world for two reasons, one positive and the other negative. Central Asia is potentially an alternative to the Persian Gulf as a major source of oil and natural gas. ${ }^{7}$ American, European and Chinese interest in Central Asia embodies similar diversification strategies designed to lessen dependence on unstable Middle Eastern governments and an unpredictable Organisation of Petroleum Exporting Countries. Central Asia offers two prominent advantages for oil consumers. First, its reserves are much larger than previously assumed and continue to be revised upwards as recovery technologies improve and prices rise. Second, the oil-production capacity of the Middle East and Saudi Arabia, which account, respectively, for $63 \%$ and $25 \%$ of the world's proven oil reserves, has stagnated over the

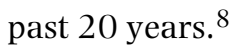

American, Chinese and Russian interest in Central Asia is driven by the fragility of Central Asian regimes and the potential threat they pose to regional stability. The difficult transition process has stalled in many cases and outstanding conflicts, territorial and other, continue to plague interstate relations and complicate the process of exploiting, extracting and delivering oil and natural gas from the region. ${ }^{9}$ The ability of the great powers, particularly China and the United States, to mitigate the causes of regional instability, to mediate interstate conflict, and to avoid the outbreak of war will largely determine whether Central Asia can become a stable and reliable source of supply. The states of the region have already proven themselves incapable of managing their own affairs and have relied heavily on outside help for solutions to the economic and political challenges attending statehood. The region remains potentially volatile owing to water-allocation conflicts, Islamic militancy and ethnic tensions. The prospects for regional peace and stability will depend, at least in the short term, on the sustained interest and intercession of the great powers, especially China, Russia and the United States.

These three powers have made sustained and competitive diplomatic overtures to the Central Asian states. The United States, for instance, has made an effort to integrate these states into the Atlantic security system via the PfP programme and the Euro-Atlantic Partnership Council. China and Russia, in turn, adopted a more traditional strategy of limited multilateralism with the creation of the 'Shanghai Five', which was later institutionalised as the SCO. Both China and the United States have sought preponderant influence, if not hegemony, in the region. Moreover, the 
Sino-American competition means that China and the United States, almost by definition, view each other's ambitions in the region as virtually inimical to each state's own interests.

Illustrative of this trend is the American marriage of convenience with Uzbekistan, which reflects Washington's effort to manage the tension between ideals and self-interest in a critical area of the world. Washington designated Tashkent a strategic partner in 1995, despite the latter government's non-democratic and totalitarian nature. ${ }^{10}$ Washington's embrace of Tashkent later served the short-term American interest in the war against terrorism and reinforced the American presence in the region. That policy, however, may make long-term solutions to regional problems more difficult to come by, particularly from the need to find a multilateral solution for the routing of oil lines to eastern Asia as well as to Europe. ${ }^{11}$ The potential danger of the American intimacy with Uzbekistan is that "the inertia and the logic of events may tempt the Bush administration to let a temporary expedient grow into an enduring policy shift'. ${ }^{12}$ In other words, propping up Uzbekistan as a regional hegemon not only would fail to address, but would actually exacerbate, a key source of Central Asian instability: the domestic political repression that fosters the radicalisation of Islamist movements and galvanises popular support behind them. Moreover, viewing the Islamist threat primarily as a military problem will not mitigate the various transnational concerns plaguing the region, particularly water-allocation disputes and unwanted flows of drugs, refugees and weapons. ${ }^{13}$ This danger is particularly acute since the Caucasus and Central Asian states could become zones of interstate competition similar to that in the Middle East or the Korean peninsula. The intensification of war in Chechnya and the evolution of post-Taliban Afghanistan already point to the region's potential for 'Balkanisation'. Were this process to accelerate and spread throughout the region, it could precipitate military intervention by any one of the regional or global major powers, including Turkey and Iran, both of which threatened to intervene in the Nagorno-Karabakh war in 1992-93. ${ }^{14}$

A second negative development in the region is the gradual shift in the goals and objectives of the SCO. Russia, and particularly China, are potential challengers to the American design for and role in the region. The SCO, for instance, shifted its focus from the resolution of border conflicts and enhanced economic cooperation to addressing the common problem of Islamic militancy when the members established an 'anti-terrorism centre' in Biskek (Kyrgyzstan) in 1999. Although the SCO claims that the sole purpose of the Biskek centre reflects a growing recognition of the threat posed by terrorism to the region, the United States has not fully accepted that explanation. Rather, the Bush administration suspected that it was a harbinger of a joint Sino-Russian strategy of eventually stationing Chinese and Russian troops in Central Asia, moving towards creating a military and political bloc. But this fear has been allayed by the evolution of the 
Russian-American relationship, particularly the amicable personal relationship of the presidents, George Bush and Vladimir Putin, and Russia's virtual de facto membership of NATO. Russia's concern with the SCO has changed correspondingly. No longer interested in creating a balancing alliance against the United States, Russia now sees the SCO as an institutional basis enabling it to act as Asia's interlocutor with the United States. Sino-American relations have not experienced a similar evolution. Washington and Beijing remain suspicious of each other's intentions and strategic interests, particularly in Central Asia. In the Chinese strategic calculus, the SCO remains an institution designed to balance American power in the region. The United States, on the other hand, suspects that China's ultimate objective is Chinese hegemony and an American loss of presence in Eastern and Central Asia. ${ }^{15}$

\section{American and Chinese energy policy and strategy}

Both the United States and China were forced over the course of the 1990s to reassess their growing vulnerability to disruptions in the supply of oil from the Middle East. Each has had to reconsider the economic and political consequences of an unanticipated energy shortfall, as well as the need to fashion policies that would encourage the development of new sources of oil outside the Middle East. There is a growing consensus that there may eventually be an unsustainable gap between the supply and demand for oil. ${ }^{16}$ The chief reasons for the anticipated gap between global supply and demand are attributed to the secular decline in the production of oil, limited reserves in the OPEC states, a rising demand for oil outside the wealthy countries of the Organisation for Economic Cooperation and Development, and an inadequate refining capacity. The rapid rise in oil consumption by the developing states of Asia, particularly China and India, underscores the concern over a future, major oil shortage and has accelerated the search for new sources of oil. As a Brookings Institution study warned, the "growth in international oil demand will exert increasing pressure on global oil availability', and the growth rate of Asian economies and populations - particularly in China and India - will be 'major contributors' to this increased demand. ${ }^{17}$ In a similar vein, the US Energy Information Administration projects that the demand for oil in developing Asian countries will increase by 129 percent over the next 20 years. ${ }^{18}$ Another study forecasts that China will need to import some 60 percent of its oil and at least 30 percent of its natural gas by $2020 .{ }^{19}$

The anticipated gap between the domestic supply and demand for oil has forced the Chinese government to look abroad to meet China's future energy needs. ${ }^{20}$ Similar concerns in the United States led the Department of Energy to recommend in May 2001, for example, that the Bush administration take aggressive measures to meet America's future energy needs. ${ }^{21}$ The suggested policy initiatives, particularly drilling for oil in the Arctic National 
Wildlife Preserve, pose a formidable domestic political challenge to the administration. ${ }^{22}$ A confluence of domestic politics and foreign policy imperatives has turned Chinese and American attention to Central Asia as a solution to their respective future energy requirements. The oil-rich states of Central Asia have been accorded a privileged place in the American and Chinese foreign policy calculations. As a consequence, these states may become the fodder in any Sino-American competition for geopolitical and geoeconomic predominance in the region.

The United States will face fierce competition from China and other Asian states in the race to exploit and develop Central Asian energy resources. While it is true that Asian states have been important consumers of oil, they have been content to buy that oil on the open international market rather than to undertake the capital investment necessary to discover and exploit new oil fields or lay claim to existing reserves. That time has passed. The Asian states now possess the financial and technological wherewithal to compete on a near equal footing with the European and North American oil companies. Western dominance in this area of the international economy is coming to an end, a development which will no doubt enhance the energy security of the Asian states, but at the same time diminish the energy security of Europe and North America. The Asian advantage is particularly marked in the oil-rich states of the Caspian Sea area: geopolitics will allow China and other Asian states to pose a direct challenge to the West, especially the United States, when it comes to exploiting new sources of oil and natural gas and controlling the all-important energy supply networks. The potential for conflict, rather than cooperation, has been conditioned by Chinese and American foreign policy initiatives in the region after the breakup of the Soviet Union in 1992.

\section{US policies in the region}

The Bush administration's policy in Central Asia remains very much within the framework of the Clinton administration's policy of engagement and enlargement. When the Central Asian states became independent of Soviet rule in 1992, the United States focused on promoting political and economic stability among Kazakhstan, Kyrgyzstan, Tajikistan, Turkmenistan and Uzbekistan. The goals and objectives of American policy towards the region remained congruent with those of the grand strategy pursued by the Clinton administration: to institutionalise democracy and the free market economic system; to improve human rights and underwrite the rule of law; and to stop the proliferation of weapons of mass destruction, particularly nuclear weapons. $^{23}$ At the outset, the Clinton administration sought to foster regional cooperation, relying on multilateral initiatives such as NATO's PfP and the Central Asian Economic Community (CAEC). ${ }^{24}$ The overall goal of the administration's policy was to create a favourable environment in which to achieve America's strategic goal of extending its influence in the region. 
Arguably, an important secondary strategic goal of American policy was the facilitation of energy exploration in the region by American corporations. For the Bush administration, the search for new sources of energy was close to the top of the foreign policy agenda in the region, but that goal has been displaced by the war on terrorism, a war which poses a threat to national and regional security as well as any future effort to exploit a significant, alternative source of energy. ${ }^{25}$ This fusion of America's geopolitical and geoeconomic objectives in the region has produced a constellation of policies that may persuade regional governments to favour American over European or Chinese corporations in the energy field.

The Uzbek-American relationship illustrates this fusion of the geopolitical and geoeconomic. At the outset, the United States was interested in fostering the emergence of Uzbekistan as a regional hegemon serving American interests. In the early 1990s, only Uzbekistan was viewed by the United States as a reliable partner, although some in the Clinton administration cautioned against choosing a 'preferred' customer in the region. Some analysts believed that the administration's policy was too ad hoc and insufficiently sensitive to Chinese and Russian interests in the region; others felt that the administration was too confused to promote and secure the nation's interests, not to mention the interests of corporate America. ${ }^{26}$ Arguably, the United States did lack a concrete plan for achieving stability in the region. The administration was initially unable to engage the regional leadership by identifying or creating a common or coincidental set of interests that would facilitate cooperation. Instead, it provided generous amounts of financial support in exchange for their support of American policy preferences. ${ }^{27}$ The Bush administration's war on terrorism has not provided the necessary policy coherence that would sustain cooperation over the long term, but instead has substituted a diffuse agenda with an agenda of one item terrorism.

American diplomatic activity in Central Asia prior to September 2001 focused on creating an environment that would privilege American corporations in the exploitation of regional economic and financial opportunities. The main thrust of that policy was the building of firm political connections with the Central Asian regimes and governments. ${ }^{28}$ Moreover, the United States relied on other regional actors to accomplish this end. As Edward Morse and James Richard observed, 'until September 11, the United States pursued two often conflicting goals: encouraging Russia to better protect US corporate investment in the Russian energy sector, and assisting the Caspian countries in developing and exporting their own hydrocarbons, thereby avoiding pipelines routes through Russia'. ${ }^{29}$ Thus, the United States sought to engender political stability in the region - either by its own efforts or the efforts of others - to facilitate the exploration of Central Asian oil and natural gas fields. After September 11, however, energy interests were conjoined to the war against terrorism. This change in the definition of American security 
interests led the Bush administration to forge stronger bilateral political and military relationships with the regional states. The consequence of the administration's foreign policy shift was a significant change in the regional balance of power.

The Bush administration's response to the terrorist attack on the World Trade Center and the Pentagon has had the collateral effect of furthering its long-term objectives in Central Asia; viz., creating a political environment conducive to the exploration of the region by American energy firms and to a regional military and political order conducive to the furthering of American strategic interests vis-à-vis China. In the process, however, the United States could not escape the dilemma of protecting its strategic and political interests - responding to the terrorist threat and gaining privileged access to Caspian Sea oil - at the familiar cost of its rhetorical dedication to American values, democracy, freedom and liberty, the inescapable and persistent tension between ideals and self-interest identified by Robert Osgood over fifty years ago. ${ }^{30}$ As in the past, the Bush administration opted to protect its interests at the expense of its professed ideals. As noted by Pauline Jones Luong and Erika Weinthal, the war against al-Qaeda and the Taliban required the United States to enlist Uzbekistan's authoritarian ruler, Islam Karimov, who has long been regarded as one of the region's most undemocratic and repressive leaders. ${ }^{31}$ None the less, the United States succeeded in securing access to Uzbek air bases to station its troops, airplanes and helicopters and to make use of Uzbek territory to launch offensive strikes on Afghanistan. In exchange, Uzbekistan received \$125 million in grants between September 2001 and January 2002. ${ }^{32}$

On the surface, the evolution of US policy in Central Asia could be seen as facilitating the exploration and development of new sources of oil and natural gas by American corporations. However, regional instability and volatility demands more than a diplomatic environment facilitating the signing of contracts. It requires, instead, a long-term American commitment to regional stability in order to reduce the financial risks attending the exploration and development of new energy sources. Thus, American policy has had to shift from the relatively painless task of facilitating contracts between American firms and regional governments to the more difficult and costly task of ensuring regional political stability.

\section{Chinese policy in the region}

Beijing's original goals and interests in Central Asia are still very much directed towards mitigating ethnic conflicts along its borders, the favourable resolution of outstanding border conflicts, and other non-military threats like drugs and ethnic unrest. ${ }^{33}$ In recent times, however, the Chinese orientation has evolved along lines similar to those of the United States: China is increasingly concerned with the task of ensuring a secure supply of energy, and views Central Asian oil and natural gas reserves as central to that strate- 
gic necessity. ${ }^{34}$ China is now actively involved in Central Asian energy exploration, which reflects China's long-standing fear of dependency on uncertain sources of foreign supply. ${ }^{35}$

As China's economy continues to grow, its demand for all sources of energy, notably oil and natural gas, will increase. Oil demand is projected to grow at an average annual rate of 3.8 percent during the period of 1996-2020, increasing consumption from 3.5 to 8.8 million barrels per day. In tandem with the rising demand for oil, China's domestic reserves and production have steadily declined. Conservative estimates of Chinese oil reserves indicate a reserves/production ratio of just 20 years. On the brighter side, the share of oil in China's primary energy consumption will remain at 20 percent, in part because of the Chinese government's effort to expand natural gas production and consumption. ${ }^{36}$

Natural gas demand is expected to grow at an average annual rate of 11.7 percent over the same period, increasing consumption from 0.7 to 9.5 trillion cubic feet. China's demand for natural gas is growing at a more rapid pace than that for other sources of energy, with the result that natural gas is expected to grow from 2 percent of China's energy consumption in 1996 to 11 percent in 2020. Rising natural gas consumption will be largely responsible for the projected decline in the use of coal from 73 percent to 65 percent of total energy consumption between 1996 and 2020, although demand for coal is still expected to grow at an average annual rate of 3.6 percent during this period. ${ }^{37}$

Besides the recent decline in China's domestic oil exploration and production, there are two other reasons why China has sought to develop both domestic and foreign natural gas reserves: to end chronic energy imbalances and shortages; and to stem rising petroleum imports. ${ }^{38} \mathrm{China}$ has been faced with sporadic, yet chronic, energy imbalances and shortages. The uncertain rate of future economic growth makes it very difficult to predict Chinese energy needs with any precision. ${ }^{39}$ To reduce uncertainty, China made two strategic decisions in the 1990s regarding its future energy needs. First, as it became clear that the volume of crude oil imports was set to rise dramatically, China started to import ever-larger quantities of oil from the Middle East and to diversify its sources of supply. ${ }^{40}$ Second, the government committed its state-owned enterprises in the oil business to undertaking substantial international investments related to the extraction of oil and gas resources, as well as to the improvement of transport networks. ${ }^{41}$ In general, the overall purpose and intention behind these decisions were to ensure that China would have the energy supplies necessary to sustain its future economic growth.

China will play a more active role in Central Asian energy politics in the coming decade, which may well bring it into conflict with America's strategic goals in the region. China is already engaged in one energy exploration project in Iran and is refurbishing two refineries for oil swaps from the 
Caspian region; China has committed substantial financial resources for oil exploration in Kazakhstan; Chinese service companies are active in Turkmenistan; and China hopes to increase oil and gas shipments from Turkmenistan via Iran. As important, China plans to commit capital to build long-distance pipelines running to and from the region. Moreover, the seriousness of the Chinese concern about its future energy security is underscored by China's long-term negotiations with the Iraqi government to secure rights to an oil field, despite the American animus towards Saddam Hussein's Iraq and the American-led and enforced embargo on that country. ${ }^{42}$

\section{Perception and misperception in the Sino-American relationship}

The United States and China would seem to share coincidental, if not common interests and goals in the region, particularly the need to create a favourable political and strategic environment facilitating the exploitation of Central Asian oil and natural gas reserves. However, the strategies and tactics employed to achieve this goal suggest that the two states are having a different dream in the same bed. While the United States has earnestly striven to improve its political profile as the means to secure its economic interests in the region, China is fearful that an American presence in the region will frustrate its own pursuit of not dissimilar objectives. Historically, China has been discomfited by the presence of a great power along its border and has sometimes responded militarily, the Chinese intervention in the Korean conflict providing the prime example. The heightened American profile in Central Asia and the indefinite basing of American troops in China's backyard suggests that the United States runs the risk of inflaming Chinese suspicions of American intentions and ambitions in the region.

There has been a progressive realignment of the American military presence in Asia during the past decade. The United States has very slowly, perhaps haphazardly, crept into the Chinese neighbourhood - from Singapore to Indonesia, from the United Arab Emirates to Oman, and now from Uzbekistan and Pakistan to Kazakhstan. This development reinforces the Chinese preoccupation with an American strategy of neo-containment in Asia. ${ }^{43}$ How is China going to perceive and react to this untoward change in its external environment? Will the US military presence in the region have a negative or positive effect on China's effort to secure a new channel of supply from Central Asia? A similar question can also be raised with respect to the Indian Ocean and South China Sea lanes: how will American policy towards Southeast Asia affect Chinese strategic thinking and its future acquisition of foreign oil and natural gas? What are the consequences of a Sino-American dispute over issues of territorial sovereignty (i.e., the Taiwan question) or the direction of the pipelines from Central Asia?

China and the United States are wary of one another's interests and inten- 
tions in Central Asia, a legacy of their postwar relationship and different conceptions of international order. Real conflicts of interest, which are magnified by mutual misunderstandings and misperceptions, will inevitably complicate the task of developing, extracting and delivering oil and natural gas from the region. Two examples illustrate this mutual wariness. First, the United States perceived the 'Shanghai Five' and the subsequent SCO as a military alliance aimed against the United States and as a mechanism for isolating it in the region, if not excluding it from the region. ${ }^{44}$ The Bush administration in particular regarded the $\mathrm{SCO}$ as a platform for joint RussoChinese denunciations of American policies and as the legal basis for enabling either Russia and/or China to project military force into the area. The administration also assumed, incorrectly, that the SCO would be manipulated to enhance Chinese leverage with Russia on the Taiwan question. The American preoccupation with a set of unfounded strategic assumptions about the purpose of the SCO and the idée fixe that China is a "peer competitor' have distracted attention from the Chinese effort to defend its interests in Central Asia against separatism, terrorism and Islamic extremism - areas where the United States and China should be able to find common ground. ${ }^{45}$ The fundamental logic informing the Bush administration's understanding of the SCO has reflected the deeply held assumption that China seeks regional hegemony and the diminution of the American presence in the western Pacific. The administration's pessimism about the destabilising role of the $\mathrm{SCO}$ - at least from the American perspective - has been reinforced by the inevitable competition for Central Asian oil and natural gas. Although the SCO cannot be viewed as an institution that is capable of excluding the United States from the region, it can be viewed as a regional effort to check American influence. None the less, the SCO is likely to have a limited impact on the American freedom of action for two reasons: first, the emerging framework of understanding in Europe between the United States and the Russian Federation is likely to spill over into Central Asia; and second, China cannot yet act alone against the United States without Russian support. ${ }^{46}$

Were one to persist in arguing that the SCO presents a serious challenge to the US role in Central Asia, it would be equally clear that the ongoing American military and political penetration of Central Asia presents a direct challenge to China. First, the American military action taken in Afghanistan has certainly shifted the regional balance of power in the American favour. The United States has concluded military cooperation agreements with Uzbekistan, Kyrgyzstan and Kazakhstan. Second, these agreements have laid a solid foundation for the United States to realise its long-sought objective of expanding its political influence in regional affairs. With a military presence legitimised by a set of bilateral agreements, the United States is now in a much better position to secure and promote its energy interests in the region. Third, the US military presence is indefinite and provides a source of considerable anxiety for China, which 'would prefer not to have the US next 
door (again), as it did during the wars in Vietnam and Korea' ${ }^{47}$ The stationing of 1,000 American troops in Uzbekistan, a limited deployment by any standard, has had important regional implications. Although those troops were tasked to provide security for an airport central to the success of the war against the Taliban and al-Qaeda in Afghanistan (as well as to the ancillary tasks of humanitarian aid and search-and-rescue missions), Uzbekistan now provides the staging ground for military action against any regional power threatening American objectives or allies. The United States is now positioned to support the governments of Turkmenistan, Kazakhstan and Uzbekistan as well as smaller Kyrgyzstan and even the Russian client-state Tajikistan in exchange for the favourable treatment of American interests, particularly the construction of energy pipelines and major infrastructure projects in the region. This prerogative may enable the United States to determine the direction, path and end point of the energy transport networks in the region. Were the United States to wield this kind of influence, it would seriously compromise the Chinese goal of securing its own channel of supply from the region. ${ }^{48}$

\section{Conclusion: different starting point, different end point?}

The set of interests pushing China and the United States into Central Asia were initially quite different. China's engagement reflected a desire to resolve outstanding border disputes as well as ensure regional stability, which was jeopardised by the disintegration of the Soviet Union. Beijing desired stability and peace along the country's long border with the Central Asian states; it also had an equally compelling interest in stopping the transfer of arms from the radical Islamic states and terrorists in support of the Uigor minority independence movement in the Xinjiang autonomous region. ${ }^{49}$ By contrast, American policy objectives for the states of this region were not dissimilar from those held for the Russian Federation during the early years of the Yeltsin administration. The Clinton administration provided economic and financial assistance in an attempt not only to resuscitate weak regimes in the region, but to lay a strong foundation for the spread of democracy and the free market economic system.

Starting from the mid-1990s, American and Chinese policy priorities shifted towards devising foreign policies that would best develop and exploit Central Asian energy reserves towards the goal of enhancing national energy security. Neither state desires an increased dependence upon Middle Eastern oil; neither wants future economic growth held hostage to supply shortages - real or manufactured - or price rises. Despite a common interest in regional stability and the exploitation of Central Asian oil reserves, China and the United States have so far acted independently of one another. Arguably, Sino-American cooperation would be one avenue for reducing the high costs and risks attending the development of Central Asian oil and 
natural gas fields. None the less, Sino-American cooperation remains limited by the two states' deep distrust of one another, which is aggravated by their ongoing strategic competition for Pacific and Asian dominance.

The United States has sought to maintain its dominant position in the Pacific. For Beijing, the cumulative impact of the Bush administration's policies in Asia has been an increased wariness of American intentions in the region. President Bush's state visits to India and Pakistan for the first time since the late 1970s were freighted with important military and strategic implications, at least for China. In the wake of September 11, the United States has succeeded in building military posts on the basis of official military cooperation agreements that have strengthened its strategic and military position in the South China Sea, the Malacca Strait and Central Asia. ${ }^{50}$ American policy towards Russia in Europe has weakened the $\mathrm{SCO}$ as a bulwark against undue American influence in Asia; the stationing of a sizeable US military force in the region has also meant that there is now an opportunity for the weaker members of the SCO 'to escape from Russo-Chinese efforts to dominate them'. ${ }^{51}$ China is specifically worried that the Central Asian states, in siding with the United States in the war against terrorism, have traded their penury relationship with Russia and China for a much more munificent dependence on the United States. Uzbekistan and Kazakhstan, in promising Washington access to military bases, over-flight rights and intelligence sharing, have purchased insurance against a Sino-Russian condominium. The Central Asian states are engaging in a balancing diplomacy in an effort to maximise their freedom of movement, not only from Russia and China - their proximate neighbours - but from the United States were it to become an overbearing protector. Unsurprisingly, Beijing views these trends and developments as inimical to its own long-term strategic interests in Asia.

Sino-American goodwill will probably remain shallow at best and SinoAmerican cooperation episodic and contingent on shared calculations of interest. In 2001 and the first half of 2002, for instance, China and the United States have seemed to be on good terms, with China winning the hosting rights to the 2008 summer Olympics and entering the WTO as a full member in the winter of 2001. These positive developments were disrupted by the US spy plane incident on the island of Hainan in April 2001. Moreover, despite Beijing's support of the American action against terrorism in Afghanistan, tensions re-emerged when the Bush administration invited Taiwan's minister of defence to visit Washington, DC, in March 2002. This chequered recent past, which is indicative of the deep mutual mistrust existing between these two important states, in combination with their not easily reconciled strategic ambitions, suggest that the exploitation and development of Central Asian energy is an unlikely basis for Sino-American cooperation. As important, the Central Asian states may face the unpalatable choice of choosing between Washington and Beijing. 


\section{Notes}

1 Erica Strecker Downs, China's Quest for Energy Security (Santa Monica: Rand Corporation, 2000); Li Zhisheng, 'Zhongguo de Nengyuan Weiji' ('China's Energy Crisis'), in Li Ming (ed.), Zhongguo de Weiji (Xia) ( The Crisis of China II) (Beijing: Gaige chubanshe, 1998), pp. 611-30; and Wang Qingyi, 'Zhongguo de Nengyuan Weiji' ('China's Energy Crisis'), in Li Ming The Crisis of China II, pp. 631-9.

2 Liu Hong Xuan (ed.), Zhongguo Mulin Shi: Zhongguo yu Zhoubian Guanxi Shi (The History's of China Relations with its Neighbouring States) (Beijing: Shijiezhishi chubanshe, 2002), p. 227; Zhongguo Xiandai Guoji Guanxi Yanjiusuo (China Contemporary International Relations Institute) (ed.), Shanghai Hezuo Zuzhi: Xin Anquanguan yu Xin Jizhi (Shanghai Cooperation Organisation: New Security Perceptions and System) (Beijing: Shishi chubanshe, 2002); Hsue Chuntu and Xing Guangcheng (eds), Zhongguo yu Zhongya (China and Central Asia) (Beijing: Shehuikexue chubanshe, 1999); Wang Zhiyi and Pan Zhiping, 'Lishi Huigu: Zhongya de Dongdang he Xinjiang de Wending' ('History Recollection: Turbulence in Central Asia and Stability of Xinjiang'), in Pan Zhiping (ed.), Minzu Zijue, Haishi Minzu Fenlie: Minzu he Dangdai Minzu Fenlie Zhuyi (Ethnic Sovereignty or Ethnic Separatism) (Urumuchi: Xinjiangrenmin chubanshe, 1999), pp. 228-80; and Xing Guancheng, 'China and Central Asia: Towards a New Relationship', in Zhang Yongjin and Rouben Azizian (eds), Ethnic Challenges Beyond Borders: Chinese and Russian Perspectives on the Central Asian Conundrum (New York: St Martin's Press, 1998), pp. 32-49.

3 Sherman W. Garnett, 'The United States and the Caspian Basin', in Sherman W. Garnett, Alexander Rahr and Koji Watanabe (eds), The New Central Asia: In Search of Stability. A Report to the Trilateral Commission, 54 (New York: Trilateral Commission, 2000), pp. 20-38.

4 The year 1994 is significant for two interrelated reasons. First, Chinese Premier Li Peng and government representatives made their first visits to the regional states. Second, the United States, by inviting the Central Asian states into NATO's PfP program, took a first step towards enhancing its political influence in the region. See Liu (ed.), China's Neighbour History, pp. 216, 222, 224.

5 In this context, Niklas Swanstro and Svante E. Cornell note that the inclusion of Uzbekistan in the SCO in 1999 was a success for Chinese and Russian foreign policy. See Niklas Swanstro and Svante E. Cornell, 'China's Trepidation in Afghanistan', Central Asia Caucasus Analysts (Washington, DC: Central Asian Caucasus Institute, Johns Hopkins University, 10 October 2001), p. 5.

6 David M. Lampton, 'Small Mercies: China and America after 9/11', National Interest, 66 (2001/02), pp. 106-13.

7 Estimates show that Central Asia, including Azerbaijan, has oil and natural gas reserves which could make the region the world's second most important source of energy exports by 2020. See Anthony H. Cordesman, The US Government View of Energy Developments in the Caspian, Central Asia, and Iran (Washington, DC: Center for Strategic and International Studies, 2000).

8 Edward L. Morse and James Richard, 'The Battle of Energy Dominance', Foreign Affairs, 81:2 (2002), pp. 16-31, esp. p. 23.

9 The high cost and low return of exploiting oil reserves in the near and mid-term is discussed in Downs, China's Quest, pp. 20-40; Zhang Wenmu, Zhongguo Xin 
Shiji Anquan Zhanlue (China's Security Strategy in the New Century) (Jinan: Shandongremin chubanshe, 2000), p. 179; and Morse and Richard, 'Battle of Energy Dominance', p. 25.

10 Uzbekistan was an attractive diplomatic partner for the United States, because it was the nation with the strongest pro-American sentiment in the region, it possessed a significant military force and infrastructure, and it was not a member of the 'Shanghai Five'. The Uzbek-American relationship could be seen as an effort to thwart the development of a Sino-Russian coalition in central Asia. See Robert M. Cutler, 'Cozying up to Karimov?', A Global Affairs Commentary, Foreign Policy in Focus, 4 October 2001.

11 See Robert M. Cutler, 'U.S. Intervention in Afghanistan: Implications for Central Asia', A Global Affairs Commentary Foreign Policy in Focus, 21 November, 2001; 'China Schemes to Win Support Against the US', Financial Times (13 June 2001).

12 Mark Burles, Chinese Policy Toward Russia and the Central Asian Republics (Santa Monica: Rand Corporation, 1999).

13 Pauline Jones Luong and Erika Weinthal, 'New Friends, New Fears in Central Asia', Foreign Affairs, 81:2 (2002), pp. 61-70.

14 Robert M. Cutler, 'The Key West Conference on Nagorno-Karabakh: Preparing Peace in the South Caucasus?', A Global Affairs Commentary, Foreign Policy in Focus, 4 October 2001; and Fiona Hill, 'The Caucasus and Central Asia', Policy Brief No. 80 (Washington, DC: Brookings Institution, May 2001), p. 1.

15 See Cutler, 'U.S. Intervention'; and Thomas J. Christensen, 'Posing Problems without Catching Up: China's Rise and Challenges for U.S. Security Policy', International Security, 25:4 (2001), pp. 5-40.

16 For the United States, see Department of Energy, New Energy Policy Report (Washington, DC: GPO, May 2001); National Energy Policy Development Group, National Energy Policy: Reliable, Affordable, and Environmentally Sound Energy for America's Future (Washington, DC: GPO, May 2001); and National Energy Policy Development Group, 'Strategic Energy Policy: Challenges for the 21st Century', Baker Institute Study No. 15 (April 2001). For China, see Li Peng, 'Xin Nengyuan Zhengce' ('New Energy Policy'), Renmin Ribao (People's Daily), 28 May 2002; Zhou Fengqi, Prospect of Petroleum and Natural Gas Supply and Demand in China and in the World by 2010 and by 2020 (Beijing: Energy Resources Institute, State Development Planning Commission, November 1998); and Ni Weidong, Li Zheng and Xue Yuan, 'National Energy Futures Analysis and Energy Security Perspective in China', and Shi Zulin and Xu Yugao, 'The Impact of China's Accession to the World Trade Organization on China's Energy Sector', papers presented at Strategic Thinking on the Energy Issue in the 10th Five-Year Plan (FYP) Workshop on East Asia Energy Futures, Beijing, June 2000.

17 See Fiona Hill and Regine Spector, 'The Caspian Basin and Asian Energy Markets', Conference Report No. 8 (Washington, DC: Brookings Institution, September 2001), p. 1.

18 Ibid.

19 Downs, China's Quest, p. xi.

20 Hill and Spector, 'Caspian Basin'; Sergei Troush, 'China's Changing Oil Strategy and its Foreign Policy Implications', CNAP Working Paper (Washington, DC: Brookings Institution, 1999); Burles, Chinese Policy; Zhang, 
China's Security Strategy, pp. 173-5; China Contemporary International Relations Institute, 'Nengyuan Anquan Shingshi' ('Energy Security Situation'), in Strategic and Security Review 2001/2002 (Beijing: Shishi chubanshe, 2002), pp. 129-54.

21 Department of Energy, New Energy Policy Report.

22 See National Energy Policy Development Group, National Energy Policy.

23 See Garnett, 'United States and the Caspian Basin', pp. 23-31; and Stephen Blank, 'The United States and Central Asia', in Roy Allison and Lena Jonson (eds), Central Asian Security: The New International Context (Washington, DC: Brookings Institution, 2001), pp. 127, 146.

24 Luong and Weinthal, 'New Friends, New Fears', p. 61.

25 See National Energy Policy Development Group, National Energy Policy; Denise A. Bode, 'Energy Shortage in Energy-Rich America: Why?', Heritage Lectures (Washington, DC: Heritage Foundation, 16 November 2000); Charli Coon and James Phillips, 'Strengthening National Energy Security by Reducing Dependence on Imported Oil', Backgrounder (Washington, DC: Heritage Foundation, 24 April 2001).

26 See, Blank, 'United States and Central Asia', p. 143; Cutler, 'U.S. Intervention in Afghanistan'; and Luong and Weinthal, 'New Friends, New Fears', p. 61. According to critics of the Clinton administration's policies in the region, American policy interests amounted to a laundry list of likes and dislikes that shifted in response to crises and lacked a stable set of policy preferences. Instead, issues 'such as oil and gas pipelines, conflict resolution, and human rights were targeted at different junctures, but an overall strategy - which was essential given limited government resources for the regions - was never fully anticipated. As a result, American priorities were not communicated clearly to local leaders, resulting in frequent misinterpretations of intentions.' See Hill and Spector, 'Caspian Basin', p. 2.

27 The American government has provided transition and humanitarian aid and loans to Kazakhstan (\$311 million in 1994); to Kyrgyzstan (\$250 million in 1995); and to Uzbekistan (\$500 million in 1995). From 1997 to 2000, aid increased by $61 \%$, from $\$ 620$ million to $\$ 1$ billion. Furthermore, from 1997 to 2000 , further financial assistance of approximately $\$ 1$ million was made when joint military exercise or training was held. In April of 2000 when the then secretary of state, Madeline Albright, toured three Central Asian states Kazakhstan, Kyrgyzstan and Uzbekistan - an additional pledge of \$3 million was made to each state for anti-terrorism purposes. See Zheng Yu (ed.), Dulianti Shinian: Xianzhuang, Wenti, Qianjing 1991-2001 (The Ten Years of the CIS: Present Situation, Problems and Prospects 1991-2001) (Beijing: Shijie chubanshe, 2002), pp. 282-6.

28 For detailed analysis on functional relations between the US military/political interests and business interests, see Anatol Lieven, 'The (Not So) Great Game', National Interest, 58 (1999-2000), pp. 69-81.

29 Morse and Richard, 'Battle of Energy Dominance', p. 26.

30 Robert Endicott Osgood, Ideals and Self-Interest in American Foreign Policy (Chicago: University of Chicago Press, 1952).

31 Luong and Weinthal, 'New Friends, New Fears', p. 62.

32 Ibid. 
33 For an assessment of China's traditional national interests in the Central Asian region, see Hsue and Xing, China and Central Asia; Xing Guangcheng, 'China and Central Asia', in Allison and Johnson, Central Asian Security, pp. 152-70; Zhang and Azizian, Ethnic Challenges Beyond Borders; and Wang and Pan, 'History Recollection'.

34 Philip Andrews-Speed and Sergei Vinogradov, 'China's Involvement in Central Asian Petroleum: Convergent or Divergent Interests?', Asian Survey, 40:2 (2000), pp. 377-97, esp. pp. 390-3.

35 Downs, China's Quest, p. xi.

36 On the prospect of an energy shortfall in China, see Ni et al., 'National Energy Futures'; International Energy Agency, World Energy Outlook (Vienna: IEA, 1999); and Department of Energy, International Energy Outlook, 1999 (Washington, DC: GPO, 1999), pp. 141, 145.

37 Department of Energy, International Energy Outlook, 1999, pp. 141, 146-7.

38 Hill and Spector, 'Caspian Basin', p. 5.

39 Andrews-Speed and Vinogradov, 'China’s Involvement', pp. 386-7.

40 Frank C. Tang and Fereidun Fesharaki, 'China: Evolving Oil Trade Patterns and Prospects to 2000', Natural Resources Forum, 19:1 (1995), pp. 47-58; Li, 'New Energy Policy'; and Zhang, China's Security Strategy, pp. 175-9.

41 In the late 1990s, for instance, the Chinese National Petroleum Corporation committed about $\$ 800$ million on two field development projects in Kazakhstan, at Aktyubinsk and Uzen, that have total oil reserves of about 2.5 billion barrels. See Burles, Chinese Policy, pp. 23-5; and Andrews-Speed and Vinogradov, 'China's Involvement', p. 389.

42 Hill and Spector, 'Caspian Basin', p. 7; and Andrews-Speed and Vinogradov, 'China's Involvement', p. 377.

43 China Contemporary International Relations Institute, Strategic and Security Review: 2001/2002, pp. 61-79; and Zhang, China's Security Strategy, pp. $166-72$.

44 Bates Gill, 'Shanghai Five: An Attempt to Counter US Influence in Asia?', Newsweek Korea (May 2001).

45 It is difficult to understand how anyone could view the SCO as potential legal cover for a joint Sino-Russian military action against Taiwan. See Stephen Blank, 'Towards Geostrategic Realignment in Central Asia', Central Asia-Caucasus Analysts (Washington, DC: Central Asia-Caucasus Institute, Johns Hopkins University, 10 October, 2001), p. 7.

46 Swanstro and Cornell, 'China’s Trepidation'; and Lena Johnson and Roy Allison, 'Central Asian Security: Internal and External Dynamics', in Allison and Johnson Central Asian Security, p. 19.

47 Swanstro and Cornell, 'China's Trepidation'.

48 Robert M. Cutler, 'Central Asian Energy and Security in Light of the Afghanistan Crisis', Central Asia-Caucasus Analysts (Washington, DC: Central Asia-Caucasus Institute, Johns Hopkins University, 10 October 2001), p. 9; and Blank, 'Towards a Geostrategic Realignment', p. 7.

49 Andrews-Speed and Vinogradov, 'China's Involvement', p. 380.

50 The reintroduction of American forces into the Philippines to fight terrorist cells linked to al-Qaeda has led some to call for the restationing of American troops on a permanent basis. See Paolo Pasicolan, 'Strengthening the U.S.-Philippine 
Alliance for Fighting Terrorism', Executive Memorandum (Washington, DC: Heritage Foundation, 13 May 2002).

51 Blank, 'Towards Geostrategic Realignment in Central Asia', p. 7. 